\title{
Single nucleotide polymorphisms for genes encoding cytokines in the context of cardiac surgery. Part I: Heart transplantation
}

\author{
Aleksander Danikiewicz', Janusz Szkodzinski², Bartosz Hudzik², Ilona Korzonek-Szlacheta ${ }^{1}$, \\ Mariusz Gąsior², Lech Polonski², Barbara Zubelewicz-Szkodzińska ${ }^{1}$ \\ ${ }^{1}$ Department for the Prevention of Food-related Diseases, School of Public Health, Medical University of Silesia, \\ Katowice, Poland \\ 2Third Chair and Department of Cardiology, Medical University of Silesia in Katowice, School of Medicine \\ with the Division of Dentistry in Zabrze, Silesian Center for Heart Diseases in Zabrze, Poland \\ Kardiochirurgia i Torakochirurgia Polska 2015; 12 (1): 48-52
}

\begin{abstract}
Cardiovascular diseases remain the leading cause of death in Poland and other countries of the European Union. Patients with end-stage heart failure constitute a patient subgroup for whom the treatment of choice is heart transplantation. Despite advances in immunosuppressive therapy, acute or chronic graft rejection occurs in $20-30 \%$ of cases in the first six months after transplantation. The significance of the immune response and inflammation in graft rejection implies the important role of cytokines. Molecular markers are sought to facilitate risk assessment and improve patient care. At present, genetic tests are not used for this purpose, but studies aiming to rectify that have been conducted for years, including studies on single nucleotide polymorphisms of cytokine genes. This paper presents the results of research on the single nucleotide polymorphisms (SNPS) of the IL-2, IL-4, IL-6, IL-10, TGF- $\beta 1$, PDGF, VEGF, and TNF- $\alpha$ genes in conjunction with heart transplantation. The analyzed data do not allow for reliable application of these genetic tests in clinical practice, but suggest that it is a promising direction which may improve the options of treatment individualization in the future.
\end{abstract}

Key words: cytokines, single nucleotide polymorphisms, SNP, heart transplantation.

\section{Introduction}

In spite of the introduction of intensive prophylactic measures and the allocation of considerable funds and effort, diseases of the circulatory system remain the most frequent cause of death in Poland and other countries of the European Union [1]. Although patients with ischemic heart disease constitute the most numerous group of patients suffering from diseases of the circulatory system,

\section{Streszczenie}

Choroby układu krążenia pozostają najczęstszą przyczyną zgonów. Szczególną podgrupę stanowią przypadki schyłkowej niewydolności serca, gdzie leczeniem z wyboru jest transplantacja. Pomimo postępów w leczeniu, ostre i przewlekłe odrzucenia przeszczepu dotyczą 20-30\% przypadków w pierwszych 6 miesiącach po transplantacji. W odrzucaniu przeszczepu kluczową rolę odgrywają reakcje immunologiczne i stan zapalny, a więc również cytokiny. Poszukiwane są markery molekularne mogące pomóc w lepszej ocenie ryzyka i opiece nad pacjentem z wysokim ryzykiem odrzutu. Obecnie nie wykorzystuje się do tych celów badań genetycznych, ale prace w tym kierunku są prowadzone od lat, a wśród nich badania polimorfizmów pojedynczych nukleotydów genów cytokin. W niniejszym opracowaniu przedstawiono wyniki prac nad polimorfizmami pojedynczych nukleotydów (single nucleotide polymorphisms - SNP) genów IL-2, IL-4, IL-6, IL-10, TGF- $\beta 1$, PDGF, VEGF, TNF- $\alpha$ w powiązaniu $z$ transplantacją serca. Wyniki te nie pozwalają na wiarygodne zastosowanie tych oznaczeń genetycznych w praktyce klinicznej, ale wyznaczają ciekawy kierunek badań, które w przyszłości poszerzą nasze możliwości indywidualizacji leczenia.

Słowa kluczowe: cytokiny, polimorfizmy pojedynczych nukleotydów, SNP, transplantacja serca.

cardiac surgeons cannot neglect other cardiac disorders requiring surgical intervention, including end-stage heart failure, for which the treatment of choice is transplantation. In recent decades, enormous progress has been achieved in the field of transplant therapy; notwithstanding, the issue of complications influencing patient survival remains problematic. Acute and chronic graft rejection are unfavorable events after heart transplant procedures, oc-

Address for correspondence: Aleksander Danikiewicz, Department for the Prevention of Food-related Diseases, School of Public Health, Medical University of Silesia, 18 Piekarska St., 41-902 Bytom, phone: +48 792777 233, e-mail: adanikiewicz@sum.edu.pl, a.danikiewicz@gmail.com 
curring in approximately $20-30 \%$ of cases within the first six months after allotransplantation [2]. This is why experts continue their search for molecular markers that will enable the stratification of patients in whom the risk of graft rejection is high. The process of inflammation plays a substantial role in atherosclerosis development, but it is also significant with regard to tissue stress and injury occurring during surgical procedures as well as its participation in the development of unfavorable effects of heart transplantation: development of vasculopathy and incidents of graft rejection. It is important to consider vascular endothelial dysfunction and the concurrent activation of inflammatory mediators, including cytokines and growth factors, which influence the migration of cells into the site of endothelial injury (inflammation site) as well as their growth.

To date, substantial effort has been made to develop tools that would enable the assessment of the risk of both the cardiac surgery procedure itself and its postoperative course in order to identify patients with elevated risk and qualify them for procedures offering the best chance for recovery. In current practice, this assessment is based on clinical data: medical history, diagnosis of concomitant disorders, and results of laboratory and imaging examinations; however, these data can only partially facilitate the prediction of the short- and long-term outcomes of heart transplantation. At present, genetic examinations are not routinely used for this purpose, although studies aiming to rectify that have been conducted for over a decade. For now, they are not numerous, but they do yield interesting results. One interesting aspect of genetic research is the study of singlenucleotide polymorphisms (SNPS), consisting in the evaluation of changes within single base pairs in identified genes. For the last several years, SNP studies have dominated the research on polymorphisms of genes, including cytokines. Single-nucleotide polymorphisms (SNPs) constitute the most common form of genetic variety in humans, and each SNP entails a difference of a single nucleotide, i.e. a "brick" of which DNA is constructed. E.g., a given SNP may entail the substitution of cytosine (C) with thymine $(T)$ in a particular location of the DNA thread. The occurrence of SNPs is common, $1: 300$ nucleotides on average, which means that their number may reach as many as 10 million. Typically, they are present in DNA fragments between the genes and have no impact on the organism's development and health - they are used as markers facilitating gene localization. However, if an SNP appears within the gene or the regulating region of DNA, it may influence its functioning, potentially impacting disease development, reaction to some agents, the ability to adapt to environmental factors, etc.

Many SNPS have already been identified, but their clinical significance remains unknown or uncertain in most cases. It can be reasonably surmised that only a small portion of them can be of medical use, but determining this is impeded by many factors, e.g. varying SNP distribution in different populations (e.g., depending on race and/or region of the world) [3]. Single-nucleotide polymorphisms studies are conducted on DNA obtained from patients (usu- ally from blood samples); the samples may be tested not only when the disease occurs, but also before or after this event, which allows researchers to conduct both prospective and retrospective studies. We assume that these SNPs were transmitted by parents. Polymorphism entails the occurrence of two or more forms of a given gene within a population with a frequency of more than $1 \%$, i.e. larger than the result of preserved mutation. Notwithstanding, both polymorphisms and mutations are the results of changes within the DNA sequence.

Considering the clinical aspect, gene polymorphisms may result in differences in susceptibility to post-transplant complications, time of symptom occurrence, and complication severity.

The aim of this paper is to present the results of studies on the SNPS of the genes of pro- and anti-inflammatory cytokines in the context of heart transplantation and other cardiac surgery procedures.

\section{Transforming growth factor $\beta 1$}

Transforming growth factor $\beta 1$ (TGF- $\beta 1$ ) has been the object of the largest number of studies related to the subject matter of the present analysis. It is a multifunctional cytokine produced by all cells of the human body [4], which plays a key role in wound healing and in processes related to the extracellular matrix [5]; its excessive production, however, may lead to increased fibrosis and scarring [6] Furthermore, TGF- $\beta 1$ has strong immunosuppressive properties [7].

Two studies by Densem et al. described the influence of TGF- $\beta 1$ SNPs on the development of cardiac transplant-related coronary vasculopathy (CV). Based on the evaluation of 129 individuals, the first study found that, in the case of TGF- $\beta 1$ polymorphism $+915 \mathrm{C} / \mathrm{G}$, C allele carriers (CC and CG genotypes - associated with low/intermediate production of this cytokine; constituted $10.9 \%$ of the study group) are less susceptible to CV development, while the presence of the GG genotype (high TGF- $\beta 1$ production) is a significant risk factor for CV development $(\mathrm{HR}=3.01 ; p=0.042)$ [8]. The mean time of CV development was 1240.5 days in GG homozygotes in comparison to 2266.5 days in C allele carriers. The second study examined 147 patients and 134 transplant donors with the focus on SNPs at positions +915 and +869 of the TGF- $\beta 1$ gene [9]. The results of the previous work were confirmed with regard to GG homozygous donors (but not recipients) with TGF- $\beta 1$ polymorphism at position $+915 \mathrm{C} / \mathrm{G}$. In the case of the second polymorphism, no association was observed between the presence of specific alleles in either the donors or the recipients with CV development; therefore, it was concluded that it cannot be used as a genetic risk factor.

Bijlsma et al. examined four TGF- $\beta 1$ SNPs at positions $-800,-509,+869$ (codon 10), and +915 (codon 25) in 70 donors and 61 recipients of heart transplants without finding any relationship between the individual genotypes and the appearance of acute graft rejection [10]. Notwithstanding, the authors point to the fact that TGF- $\beta 1$ participates in 
the chronic rather than acute processes of rejection (which appears to be corroborated by the aforementioned work by Densem et al.).

In one of the most recent publications, which provided a meta-analysis of previous studies, Yongcharoen et al. reported that, in the case of polymorphisms TGF $\beta 1-\mathrm{c} 10$ (+869T/C) and TGF $\beta 1-C 25$ (+915C/G), C allele carriers may be less susceptible to graft rejection than $\mathrm{T}$ and $\mathrm{G}$ allele carriers (respectively, $13 \%$ and $30 \%$ lower risk; $\mathrm{Cl}$ of OR 0.65 1.18 and 0.40-1.23), but the authors also underscored that the statistical significance of their findings was insufficient and required continued research [11].

In another study, focusing on renal insufficiency in heart transplant recipients, Klauke et al. found no evidence for the influence of the TGF $\beta 1-c 10$ (+869T/C) or TGF $\beta 1-c 25$ $(+915 \mathrm{C} / \mathrm{G})$ SNPs on renal dysfunction in the studied patients [12].

\section{Tumor necrosis factor $\alpha$}

Tumor necrosis factor $\alpha$ (TNF- $\alpha$ ) is one of the key proinflammatory cytokines, and its polymorphism has been linked with kidney and liver graft rejection [13, 14]. The aforementioned meta-analysis concerning TGF- $\beta 1$ polymorphisms also described the SNP of TNF $\alpha$ at position -308G/A [11]. In the case of this polymorphism as well, statistical significance was not achieved ( $95 \% \mathrm{Cl}$ of OR: 0.46$3.01)$, but it was calculated that A allele carriers are at an $18 \%$ higher risk of graft rejection in comparison to $\mathrm{G}$ allele carriers, as additionally underscored in the conclusion of the meta-analysis. Other authors of original papers reported heterogeneous results - some found no statistically significant correlations between the TNF $\alpha-308$ G/A SNP and complication development [15-18], while others, such as Ternstrom, confirmed the associations between polymorphisms and CV and patient mortality [19]. The provided explanations mentioned the small size of the study groups and the use of intensive immunosuppressive treatment.

\section{Platelet-derived growth factor and vascular endothelial growth factor}

In the context of research on polymorphisms and heart transplantation, both these growth factors - platelet-derived growth factor (PDGF) and vascular endothelial growth factor (VEGF) - have been described in only one publication. Tambur et al. evaluated 4 polymorphisms at positions PDGF-286, PDGF-1135, VEGF-1154, and VEGF-2578 in 70 heart transplant recipients [15]. The results were the basis for the authors' conclusion that patients in whom CV developed early were more likely to carry the PDGF-286AA genotype $(p<0.03)$, and less frequently PDGF-1135CC ( $p=$ 0.01). The association between CV and the VEGF-1154GG and VEGF-2578AC genotypes was confirmed as well.

\section{Interleukin 6}

Interleukin 6 (IL-6) is a cytokine produced by activated cells of vascular endothelium, monocytes, macrophages,
T lymphocytes, NK cells, and mast cells. Its special role in the development of ischemic heart disease stems from the fact that it participates in the "acute phase" response and is secreted by most cells constituting atherosclerotic plaques (local effect). Among the studies on heart transplantation, only two papers were identified as dealing with IL-6 polymorphisms, while a substantially larger number of IL-6 studies tackled the issue of ischemic heart disease. While studying the IL-6-174G/C SNP, Densem et al. concluded that it may be an important risk factor for CV - the average time until the first confirmation of CV was 2.8 years for CC homozygotes, 3.9 years for CG heterozygotes, and 5.3 years for GG homozygotes [20]. Kaplan-Meier analysis confirmed earlier CV development in CC homozygotes: in the fifth year, $100 \%$ had confirmed CV, while this rate for the GG group was approx. $60 \%$. Therefore, the CC genotype was the strongest independent risk factor for $\mathrm{CV}(\mathrm{HR}=4.2$, 95\% Cl: 1.3-12.9, $p=0.014)$. In the other of the two studies, the IL-6 SNP was not associated with the occurrence of acute graft rejection episodes [15].

\section{Interleukin 10}

Interleukin 10 (IL-10) is an immunomodulatory cytokine produced by $T$ and $B$ lymphocytes as well as macrophages.

Bijlsma et al. examined 3 SNPs of the IL-10 gene at positions $-1082 \mathrm{G} / \mathrm{A},-819 \mathrm{C} / \mathrm{T}$, and 592C/A without finding any significant differences in the allele distribution between patients who were diagnosed with graft rejection or heart failure and patients in whom these conditions were not observed [21]. They concluded that the abovementioned markers were not useful in the assessment of future risk for these events and suggested that the general balance of Th1/Th2 was more important than the presence of polymorphisms in individual cytokine genes. Similar results, i.e., no association between IL-10 SNPs with CV, were reported by Tambur et al. [15]. Different results were reported by McDaniel et al., whose study included, among others, IL-10 SNPs at positions 1082G/A, 819C/T, and 592C/A. The authors divided the study group (65 individuals) into the following haplotype subgroups (haplotype is a collection of mutually linked SNPs transmitted together): GCC - associated with high IL-10 production (high producer) and ATA - associated with low IL-10 production (low producer). Patient groups with stages 2 and 3 A/B included a significantly lower percentage of patients from the high producer group than the patient group with stage $1 \mathrm{~A}$ (respectively, $28.6 \%$ vs. $22.6 \%$ vs. $80 \%, p<0.01$ ). The authors concluded that the genotype associated with high IL-10 production appears to be a significant protective factor against heart transplant rejection [22].

\section{Interleukin 2}

Interleukin 2 (IL-2) is a cytokine which plays an important role in the adaptive immune response, acts as a growth factor in the early phase of $\mathrm{T}$ lymphocyte activation, and participates in the apoptosis of these cells [23]. After examining the -330T/G SNP of the IL-2 gene in over 300 patients, 
Holweg et al. found no differences in the distribution of alleles and genotypes between individuals with and without acute graft rejection or CV [24]. Based on a smaller sample (67 patients), Morgun et al. reached similar conclusions; however, in another patient group (after kidney transplantation), more frequent occurrence of the TT genotype was revealed among cases with graft rejection [25].

\section{Interleukin 4}

Interleukin 4 (IL-4) is a pleiotropic cytokine produced by activated $T$ lymphocytes and mast cells. It is indispensable in the development of Th2 cells; moreover, it reduces the proinflammatory response of Th1 by inhibiting macrophage activation [26]. To date, two studies have associated IL-4 polymorphisms with the clinical course after heart transplantation; both were published in 2002 by Bijlsma et al. In the first study, the authors failed to find any relationships between the presence of the IL-4-590 SNP in donors and graft rejection occurrence [27]; the second study confirmed these results with regard to donors, but revealed that graft rejection was significantly less frequent in situations where the donor was an allele $T$ carrier, and the recipient did not have this allele. In cases in which the recipient had the T allele, this relationship was no longer significant [28].

\section{Conclusions}

In conclusion, based on the current state of knowledge regarding the subject of the present paper, the study of cytokine gene SNPS cannot be recommended as a reliable method for improving the estimation of the risk of complications after heart transplant procedures. On the other hand, it is difficult to escape the impression that it is a promising direction which will achieve clinical significance in the future. In order for this to happen, studies on much larger patient groups are required, whose design would consider the differences between distinct populations, as ethnic differences may entail differences in allele distribution among patients [3, 29]. Even greater improvements may be achieved with a multi-genetic approach assessing numerous polymorphisms whose number may reach hundreds or even thousands. Nonetheless, this field of study may have to overcome technical and financial obstacles as well as addressing psychological or ethical considerations. As the number of SNP studies in various fields of medicine is constantly rising, it is to be expected that, sooner or later, reliable data will be gathered and find use in everyday practice: first, in risk stratification (as in the currently conducted research), and then, probably, in the process of individualizing treatment.

\section{Disclosure}

Authors report no conflict of interest.

\section{References}

1. http://epp.eurostat.ec.europa.eu/statistics_explained/index.php/Causes of_death_statistics/pl (dostęp 05.11.2014 r.)
2. Hertz MI, Aurora P, Christie JD, Dobbels F, Edwards LB, Kirk R, Kucheryavaya AY, Rahmel AO, Rowe AW, Stehlik J, Taylor DO. Scientific Registry of the International Society for Heart and Lung Transplantation: introduction to the 2009 Annual Reports. J Heart Lung Transplant 2009; 28: 989-992.

3. Hassan MI, Aschner Y, Manning CH, Xu J, Aschner JL. Racial differences in selected cytokine allelic and genotypic frequencies among healthy, pregnant women in North Carolina. Cytokine 2003; 21: 10-16.

4. Blobe GC, Shiemann WP, Lodish HF. Role of transforming growth factor-b in human disease. N Engl J Med 2000; 342: 1350-1358.

5. Border WA, Noble NA. TGF-beta in kidney fibrosis: a target for gene therapy. Kidney Int 1997; 51: 1388-1396.

6. Border WA, Noble NA. Transforming growth factor-b in tissue fibrosis. N Engl J Med 1994; 331: 1286-1292.

7. Letterio JJ, Roberts AB. Regulation of immune responses by TGF-beta. Annu Rev Immunol 1998; 16: 137-161.

8. Densem CG, Hutchinson IV, Cooper A, Yonan N, Brooks NH. Polymorphism of the transforming growth factor-beta 1 gene correlates with the development of coronary vasculopathy following cardiac transplantation. J Heart Lung Transplant 2000; 19: 551-556.

9. Densem CG, Hutchinson IV, Yonan N, Brooks NH. Donor and recipient-transforming growth factor-beta 1 polymorphism and cardiac transplant-related coronary artery disease. Transpl Immunol 2004; 13: 211-217.

10. Bijlsma FJ, van der Horst AA, Tilanus MG, Rozemuller E, de Jonge N, GmeligMeyling FH, de Weger RA. No association between transforming growth factor beta gene polymorphism and acute allograft rejection after cardiac transplantation. Transpl Immunol 2002; 10: 43-47.

11. Yongcharoen S, Rattanasiri S, McDaniel DO, McEvoy M, Viwatwongkaseam C, Rojanavipart P, Thakkinstian A. Meta-analysis of cytokine gene polymorphisms and outcome of heart transplantation. Biomed Res Int 2013; 2013: 3871-3884.

12. Klauke B, Wirth A, Zittermann A, Bohms B, Tenderich G, Körfer R, Milting H. No association between single nucleotide polymorphisms and the development of nephrotoxicity after orthotopic heart transplantation. J Heart Lung Transplant 2008; 27: 741-745.

13. Thakkinstian A, Dmitrienko S, Gerbase-DeLima M, McDaniel DO, Inigo P, Chow KM, McEvoy M, Ingsathit A, Trevillian P, Barber WH, Attia J. Association between cytokine gene polymorphism and outcomes in renal transplantation: a meta-analysis of individual patient data. Nephrol Dial Transplant 2008; 23: 3017-3023.

14. Rattanasiri S, McDaniel DO, McEvoy M, Anothaisintawee T, Sobhonslidsuk A Attia J, Thakkinstian A. The association between cytokine gene polymorphisms and graft rejection in liver transplantation: a systematic review and meta-analysis. Transpl Immunol 2013; 28: 62-70.

15. Tambur AR, Pamboukian S, Costanzo MR, Heroux A. Genetic polymorphism in platelet-derived growth factor and vascular endothelial growth factor are significantly associated with cardiac allograft vasculopathy. J Heart Lung Transplant 2006; 25: 690-698.

16. Densem CG, Hutchinson IV, Yonan N, Brooks NH. Influence of tumor necrosis factor-alpha gene-308 polymorphism on the development of coronary vasculopathy after cardiac transplantation. J Heart Lung Transplant 2001; 20: $1265-1273$

17. Gourley IS, Denofrio D, Rand W, Desai S, Loh E, Kamoun M. The effect of recipient cytokine gene polymorphism on cardiac transplantation outcome. Hum Immunol 2004; 65: 248-254.

18. Bedi M, Postava LA, Murali S, MacGowan GA, Mathier M, Shears L, Kormos R, Holubkov R, London B, McNamara DM. Effect of the TNF-alpha-promoter polymorphism on cardiac allograft rejection. J Heart Lung Transplant 2004; 23: 696-700.

19. Ternstrom L, Jeppsson A, Ricksten A, Nilsson F. Tumor necrosis factor gene polymorphism and cardiac allograft vasculopathy. J Heart Lung Transplant 2005; 24: 43343-43348.

20. Densem CG, Ray M, Hutchinson IV, Yonan N, Brooks NH. Interleukin-6 polymorphism: a genetic risk factor for cardiac transplant related coronary vasculopathy? J Heart Lung Transplant 2005; 24: 559-565.

21. Bijlsma FJ, Bruggink AH, Hartman M, Gmelig-Meyling FH, Tilanus MG, de Jonge $\mathrm{N}$, de Weger RA. No association between IL-10 promoter gene polymorphism and heart failure or rejection following cardiac transplantation. Tissue Antigens 2001; 57: 151-153.

22. McDaniel OD, Roten PD, Yamout SZ, Coleman V, Aru G, Heath B, Thomas TS, Turner WW, Chatam TF, Cameron JA, Moore CK. Cytokine gene polymorphism might affect the outcome of clinical rejection in cardiac transplantation. J Applied Research 2004; 4: 68-80. 
23. Li XC, Wells AD, Strom TB, Turka LA. The role of T cell apoptosis in transplantation tolerance. Curr Opin Immunol 2000; 12: 52252-52257.

24. Holweg CT, Peeters AM, Balk AH, Uitterlinden AG, Niesters HG, Maat AP, Weimar W, Baan CC. Recipient gene polymorphisms in the Th-1 cytokines IL-2 and IFN-gamma in relation to acute rejection and graft vascular disease after clinical heart transplantation. Transpl Immunol 2003; 11: 121-127.

25. Morgun A, Shulzhenko N, Rampim GF, Medina JO, Machado PG, Diniz RV, Almeida DR, Gerbase-DeLima M. Interleukin-2 gene polymorphism is as sociated with renal but not cardiac transplant outcome. Transplant Proc 2003; 35: 1344-1345.

26. Abehsira-Amar O, Gibert M, Joliy M, Thèze J, Jankovic DL. IL-4 plays a dominant role in the differential development of Tho into Th1 and Th2 cells. J Immunol 1992; 148: 3820-3829.
27. Bijlsma FJ, van Kuik J, van Hoffen E, de Jonge N, Tilanus MG, Gmelig-Meyling FH, de Weger RA. Acute cardiac transplant rejection is associated with low frequencies of interleukin-4 producing helper T-lymphocytes rather than with interleukin-4 promoter or splice variants. Hum Immunol 2002; 63: 317-323.

28. Bijlsma FJ, vanKuik J, Tilanus MG, deJonge N, Rozemuller EH, van den Tweel JG, Gmelig-Meyling FH, deWeger RA. Donor interleukin-4 promoter gene polymorphism influences allograft rejection after heart transplantation. J Heart Lung Transplant 2002; 21: 340-346.

29. Girnita DM, Webber SA, Ferrell R, Burckart GJ, Brooks MM, McDade KK, Chinnock R, Canter C, Addonizio L, Bernstein D, Kirklin JK, Girnita AL, Zeevi A. Disparate distribution of 16 candidate single nucleotide polymorphisms among racial and ethnic groups of pediatric heart transplant patients. Transplantation 2006; 82: 1774-1780. 